\title{
The effects of ethyl acetate fraction of Ananas comosus (L.) Merr. of tongue cancer cell growth inhibition Supri's clone-1, invitro
}

\author{
Maureen Martina*), Roosje Rosita Owen*, Eriska Riyanti*, Achmad Syawqie**, \\ Supriatno***
}

*Department of Pedodontics Faculty of Dentistry Universitas Padjadjaran, Bandung

**Department of Oral Biology Faculty of Dentistry Universitas Padjadjaran, Bandung

***Department of Oral Disease Faculty of Dentistry Universitas Gajah Mada, Yogjakarta

\section{ABSTRACT}

Ananas comosus (L.) Merr has several purposes which include antioxidant and anti-inflammatory activity that shows some pharmacological effects and the subject of anti-cancer or anti-cancer supporting material. The research objective was to analyze the effects of ethyl acetate fraction of Ananas comosus (L.) Merr. of tongue cancer cell growth inhibition Supri's clone-1 (SP-C1). This type of study was a research laboratory. Next, cell growth inhibition testing by the ethyl acetate fraction of Ananas comosus (L.) Merr. with various concentrations $(0 ; 62.5 ; 125 ; 250 ; 250 ; 500$ and 1000 microgram/ml) using the MTT assay test. Growth barriers identified by Biorad microplate tool reader with a wavelength of $540 \mathrm{~nm}$. The number of SP-C1 cells examined was $2 \times 104$ cells/wells with incubation time 24 and 48 hours. Data were analyzed using a two-ways ANOVA followed by post hoc test (LSD test) with $95 \%$ significance level. The results showed ethyl acetate fraction of Ananas comosus (L.) Merr. able to inhibit the growth of cancer cells SP-C1. Various concentrations of ethyl acetate fraction of pineapple was highly significant, meaning that the concentration effect on cell growth of SP-C1. Similarly, incubation time effect on the growth of SP-C1 cells that were very meaningful. The biggest obstacle effect of ethyl acetate fraction of Ananas comosus (L.) Merr. occurred at a concentration of $1000 \mathrm{ug} / \mathrm{ml}(43.45 \%)$ with an incubation time of 48 hours. Conclusion of this study was the fraction of ethyl acetate Ananas comosus (L.) Merr. has the effect of inhibiting the growth of cancer cells SP-C1.

Key words: Ethyl acetate fraction of Ananas comosus (L.) Merr, inhibition of cell growth, cancer cells Supri's clone-1

\section{ABSTRAK}

Ananas comosus (L.) Merr memiliki beberapa kegunaan yang meliputi aktivitas antioksidan dan anti inflamasi yang menunjukkan beberapa efek farmakologis dan menjadi bahan anti kanker atau sebagai bahan penunjang anti kanker. Tujuan penelitian adalah menganalisis efek fraksi etil asetat Ananas comosus (L.) Merr. terhadap hambatan pertumbuhan sel kanker lidah Supri's clone-1 (SP-C1). Jenis penelitian yang digunakan adalah desain penelitian laboratorik. Selanjutnya, untuk menguji hambatan 
pertumbuhan sel oleh fraksi etil asetat Ananas comosus (L.) Merr. dengan berbagai konsentrasi (0; 62,5; 125; 250; 250; 500 dan $1000 \mu \mathrm{g} / \mathrm{ml}$ ) menggunakan uji MTT assay. Hambatan pertumbuhan diketahui melalui alat Biorad microplate reader dengan panjang gelombang $540 \mathrm{~nm}$. Jumlah sel SP-C1 yang diperiksa adalah $2 \times 104$ sel/sumuran dengan waktu inkubasi 24 dan 48 jam. Data dianalisis menggunakan ANAVA dua jalur dilanjutkan dengan uji Post Hoc (uji LSD) dengan taraf signifikansi 95\%. Hasil penelitian menunjukkan fraksi etil asetat Ananas comosus (L.) Merr. mampu menghambat pertumbuhan sel kanker SP-C1. Berbagai konsentrasi fraksi etil asetat nanas bersifat sangat bermakna, artinya konsentrasi berpengaruh terhadap pertumbuhan sel SP-C1. Demikian pula waktu inkubasi berpengaruh terhadap pertumbuhan sel SP-C1 yang bersifat sangat bermakna. Efek hambatan terbesar fraksi etil asetat Ananas comosus (L.) Merr. terjadi pada konsentrasi $1000 \mu \mathrm{g} / \mathrm{ml}$ (43,45\%) dengan waktu inkubasi 48 jam. Simpulan penelitian ini adalah fraksi etil asetat Ananas comosus (L.) Merr. memiliki efek menghambat pertumbuhan sel kanker SP-C1.

Kata kunci: Fraksi etil asetat Ananas comosus (L.) Merr, hambatan pertumbuhan sel, sel kanker Supri's clone-1.

\section{INTRODUCTION}

Cancer is a disease arising from the abnormal growth of body's tissue cells and can spread to other body parts that can cause death as well as becoming a common health problem in developing countries. According to data from the Basic Health Research, year 2007, the prevalence of cancer in Indonesia was 4.3 per 1000 population, and it is the seventh leading cause of death after stroke, tuberculosis, hypertension, injuries, perinatal disorders, and diabetes. World Health Organization (WHO) estimates deaths from cancer will increase 45 percent from 2007 to 2030 (from 7.9 million to 11.5 million deaths) in the world. ${ }^{1}$ Cancer not only attacks adults, but it can also attack children. The incidence of occurrence in children was less than $0.5 \%$, but cancer will become the second cause of death after accident. ${ }^{2}$ According to Cure Research for Children's Cancer, the incidence of cancer was higher in children under five years of age and between ages 15-19 years old. ${ }^{3}$

The incidence of tongue cancer was included to one of the oral cavity cancers ranges between $3-5 \%$ of all cancers in human body. One type of tongue cancer comes from the epithelial cells is squamous carcinoma cells. ${ }^{4}$

The cancer therapy commonly used is conventional therapy with chemotherapy, radiation, surgery, and combination therapy methods. ${ }^{5}$ According to the National Cancer Institute, conventional therapy may cause some side effects, such as anemia, constipation, nausea, vomiting, hair loss and infertility. ${ }^{6}$ Nowadays, natural ingredients derived from plants, whether or not plants that have been cultivated or wild plants, have been developing for chemo preventive efforts. Chemo preventive therapy is considered quite potential in helping the treatment of cancer. Some advantages of chemo preventive therapy are relatively affordable cost and the side effects are relatively small, making it safer to do but should be with a precise dose. $^{7}$

A herbal plant which fruit can be used for treatment is pineapple (Ananas comosus (L) Merr.). Pineapple is a tropical plant that can easily found in Indonesia with a relatively reasonable price. The flavor of this fruit is sweet, sweet slightly sour, and sour. It also contains a lot of water. Pineapple has many kinds of good nutrition for health, such as vitamins A, B, C, minerals, alkaloid compounds, terpenoids, phenols, and bromelain enzyme..$^{8-11}$

The active compound in pineapple is obtained through the extraction method using liquid solvent. The resulting extract contains various organic compounds, and then fractionation is performed using solvent with different polarity level to separate the extract into a single component, such as ethyl acetate. ${ }^{12}$ Several herbal studies have used ethyl acetate as one of the solvents, and it is proven that ethyl acetate has the biggest ability to get a compound in phenol than the other solvents. ${ }^{13,14}$

Phenol is contained in many plants and is consumed in relatively high amount in human diet. Over the last 20 years, some data has been 
reported related to the health of some compounds in phenol, especially flavonoid. ${ }^{15}$ Flavonoid is the biggest compound group from phenol which is reported to have anti-cancer ability, antioxidant, anti-inflammatory, and reduces the risk of heart attack. ${ }^{16-17}$

Research on the ability of phenol compound related to the growth of cancer cells was conducted by Biantoro ${ }^{18}$ on the effectiveness of ethyl acetate fraction of mangosteen peel to the inhibition of tongue cancer cells' Supri's Clone-1 (SPC1) growth. The result showed that on $125 \mu \mathrm{g} / \mathrm{ml}$ concentration with 24 hour incubation time, the inhibition of cells' growth was $41.5 \%$.

Based on the description above, the author was interested in examining the fraction of ethyl acetate in pineapple treated to human tongue cancer cells SP-C1 which was isolated from the limphonodi of carcinoma squamous cells tongue cancer patients. ${ }^{19}$ So far, research on the ability of pineapple to the inhibition of the growth of some kinds of cancer cells only uses bromelain enzyme. This research used ethyl acetate fraction in order to get all active compounds in pineapple that have moderate polarity level, and few compunds are polar.

\section{METHODS}

The type of the research was laboratory experimental research. The research used 72 samples of cancer cells treated by ethyl acetate fraction of pineapple with 2 groups of incubation time (24 and 48 hours). Each sample will got a treatment of 6 kinds of concentrations $(0 ; 62.5$; 125; 250; 500 , and $1000 \mu \mathrm{g} / \mathrm{ml}$ ).

The procedure were: Prepared 2 microplates containing 96 wells for performing the MTT Assay test in 24 and 48 hours. Furthermore, the tongue cancer cells SP-C1 was inserted to each microplate as many as $2 \times 10^{4} \mathrm{cell} /$ well, the first column was left empty for the adaptation of Biorad Microplate Reader machine. The cancer cells began to be filled to column 2-7 and each well was filled $100 \mu \mathrm{l} /$ well using a multi channel pipette. Both microplates were incubated at $37^{\circ} \mathrm{C}, \mathrm{CO}_{2} 5 \%$ for 24 hours. After 24 hour incubation, both microplates were examined by a microscope to see the cells' condition, and all RPMI solution was discarded. The vortex of each pineapple ethyl acetate concentration was inserted to each well as much as $100 \mu \mathrm{l} /$ well. The microplates were then incubated again for 24 hours for the first microplate and 48 hours for the second microplate with temperature at $37^{\circ} \mathrm{C}, \mathrm{CO}_{2} 5 \%$.

After the first microplate was incubated for 24 hours, $15 \mu$ MTT solution was added, and was incubated again at temperature of $37^{\circ} \mathrm{C}$ for 4 hours. Furthermore, the microplate was viewed by a microscope with 40x magnification and was photographed in order to see the formation of formazan. The MTT solution was then removed, then the isopropanol solution was added 100 $\mu \mathrm{l} /$ well, and there will be a colour change from yellow to purple. The solution was shaken for 5 10 minutes until it becomes homogenous, and the microplate's absorbance was viewed using the Biorad Microplate Reader with OD $540 \mathrm{~nm}$. The same procedure was given to the microplate with the 48 hour incubation time.

\section{RESULT}

The average inhibition percentage of human tongue cancer cells' growth SP-C1 is showed in Table 1. The 24 hour incubation time showed the average inhibition percentage of the cells' growth which has begun in $62.5 \mu \mathrm{g} / \mathrm{ml}$ concentration to $1000 \mu \mathrm{g} / \mathrm{ml}$ for $41.62 \%$. The same thing was showed to the 48 hour incubation time with the biggest inhibition in $1000 \mu \mathrm{g} / \mathrm{ml}$ concentration for $43.45 \%$. The greater the concentration and the

Table 1. The average inhibition percentage of human tongue cancer cells' SP-C1 growth

\begin{tabular}{lcrrrrr}
\hline \multirow{2}{*}{ Time } & \multicolumn{6}{c}{ Concentration (\%) } \\
\cline { 2 - 7 } & Control & $\mathbf{6 2 . 5}$ & \multicolumn{1}{c}{125} & \multicolumn{1}{c}{$\mathbf{2 5 0}$} & \multicolumn{1}{c}{500} & 1000 \\
\hline 24 hour & 0 & 7.21 & 15.59 & 21.03 & 38.68 & 41.62 \\
SD & 0 & 2.41 & 4.07 & 1.13 & 4.44 & 1.31 \\
48 hour & 0 & 4.63 & 15.35 & 26.52 & 41.31 & 43.45 \\
SD & 0 & 1.46 & 2.13 & 0.74 & 1.41 & 1.53 \\
\hline
\end{tabular}




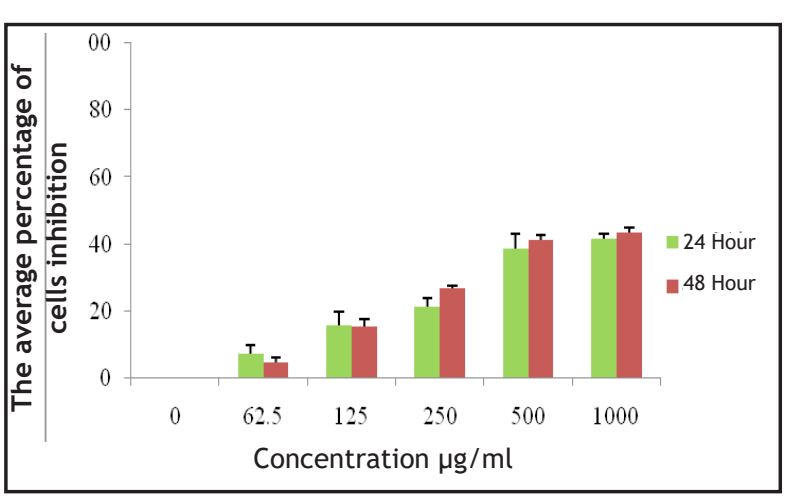

Figure 1. The average percentage of cells' inhibition growth with 24 and $\mathbf{4 8}$ hour Incubation time

incubation time, the greater the average inhibition percentage of cells' growth will be. The average inhibition percentage of human tongue cancer cells SP-C1 was figured more clearly in Figure 1.

\section{DISCUSSION}

This research aimed to analyze the fraction effect of Subang pineapple's ethyl acetate and the influence of concentration and time to the inhibition of cancer cells' growth. The type of cancer used was the culture of human tongue cancer cells SP-C1.

Table 1 showed that started from $62.5 \mu \mathrm{g} / \mathrm{ml}$ concentration, the average inhibition percentage begins to increase in 24 or 48 hour incubation time. The average inhibition of cells' growth was caused by bioactive material contained in pineapple ethyl acetate fraction that functions as a ligand capable of binding to cell receptors so that the growth of cancer cells is inhibited. ${ }^{20}$ The result of the average inhibition percentage of cells' growth in both times did not reach Fifty Inhibitory Concentration $\left(\mathrm{IC}_{50}\right)$, it means out of $100 \%$ cells' growth, the death is not greater than $50 \%$ and cells have not yet experienced the condition of saturation with 24 or 48 hour incubation time which was characterized by a decrease in the average inhibition percentage of cells' growth. This condition was probably caused by the work of herbal ingredients which needs relatively longer time than chemical medicines. ${ }^{21}$

The increase and decrease of the average inhibition percentage of cancer cells' SP-C1 growth were caused by three essential substances in herbal plants. The first was a nutritious substance that plays a role in treatment. The second substance was the companion substance for the first substance. This substance functions as side effects' reducer and enhances its usefulness as a medicine. This companion substance is called Side Effect Eliminating Substance or Secondary Efficacy Enhancing Substance (SEES) which can only be found in the residue of herbal plants fraction. The third substance was the identity substance capable of showing the identity of the original plants. ${ }^{22}$

The growth of human cancer cells SP-C1 according to the incubation time and concentration was assessed by the two-ways ANAVA test, and it gives a very significant result. By the existence of significant difference between the incubation time and concentration, a test after ANAVA test was then conducted, that was the LSD test which shows six concentrations of different pineapple ethyl acetate and gives an influence in the growth significantly. The result of this research was in line with the previous research by Biantoro ${ }^{18}$ that uses the fraction of mangosteen peel ethyl acetate to SP-C1 cells' growth inhibition in vitro. The result showed that there was cells' growth inhibition in $125 \mu \mathrm{g} / \mathrm{ml}$ concentration with 24 hour incubation time for $41.5 \%$. Another research was conducted by Hsiung and Kadir that used the fraction of Leea indica ethyl acetate. Leea indica was a Chinese herbal plant that can inhibit seven types of cancer cells. The result shows that the seven types of cancer cells experience the inhibition in cells' growth, but the biggest inhibition occurs in cervical epidermoid carcinoma cells (Ca Ski) in $200 \mu \mathrm{g} /$ $\mathrm{ml}$ concentration with 72 hour incubation time, and the inhibition of cells' growth reaches $\mathrm{IC}_{50}{ }^{23}$

Before entering cells' cycle phase, cells' growth process needs an interrelated signal transduction, and protein plays a role in this process. Receptor protein is in the cell membrane, and the ligand connected to the receptor should be sufficiently hydrophilic to be able to enter the cells. The bond between the ligand and the receptor resulting a signal cascade so that the interaction between the receptor and the effecter happens, and eventually the transcription factor into nucleus occurs. Protein kinase $\mathrm{C}(\mathrm{PKC})$ is a protein that plays a role in delivering signal transduction. ${ }^{24} \mathrm{PKC}$ is cyclic nucleotide enzyme that phosphorylate serine and threonine residues in some target protein. PKC plays an important role as the extracellular stimulation mediator including proliferation, 
differentiation, and apoptosis. ${ }^{25}$

Pineapple bioactive compound is obtained through ethyl acetate fraction which, according to several studies, has the greatest ability to get phenol compound. ${ }^{13,14}$ Phenol compound is a secondary metabolite derived from phosphate pentose, shikimate, and phenilpropanoid. Phenol is one of bioactive compounds mostly found in herbal plants and has physiological natures, such as anti-allergic, anti-inflammatory, anti-thrombotic, and has vasodilatation effect. Antioxidant activity is the main activity of phenol. ${ }^{26}$ Flavonoid belongs to one of the biggest phenol compounds, and has been reported to possess a signal cascade influence in phosphoinositide 3-kinase (PI3-kinase), Akt/ protein kinase B, tirosin kinase, PKC, and MAPK. ${ }^{27}$ Some flavonoid compounds contained in pineapple extract based on the research by Mhatre et al. ${ }^{28}$ were quercetin, flavones-3-ols, flavones and cinnamic acids. ${ }^{28}$

Herbal research on quercetin on the growth of cancer cells has been reported. Among others, a study by Kang and Liang ${ }^{29}$ on leukemia cells $\mathrm{HL}-60$, resulted that quercetin was capable of inhibiting cells' growth, cells' cycle, PKC activity, and protein tirosin kinase (PTK). Another study conducted by Woude et al. ${ }^{30}$ proved that quercetin was able to inhibit signal transduction, including phosphatidyl-inositol-3-kinase, PKC, dan PTK.

The mechanism of the inhibition of human tongue cancer cells SP-C1 by pineapple ethyl acetate fraction has not been known yet, but the research result shows that the inhibition of human tongue cancer cells SP-C1 probably occurs due to the inhibited high PKC phosphorylation in human tongue cancer cells SP-C1 by bioactive compound from phenol, especially flavonoid. In cancer, the inhibited PKC phosphorylation will cause the inhibition of MAPK phosphorylation, so that cells' growth process can be inhibited. Based on overall result and discussion, pineapple ethyl acetate has an effect on the inhibition of SP-C1 tongue cancer cells' growth and the inhibition of cells' growth depends on the concentration and incubation time treatment.

\section{CONCLUSION}

The conclusion of the research is the fraction of pineapple ethyl acetate has the inhibition effect on SP-C1 human tongue cancer cells' growth in both incubation time. The incubation time is 24 hours, the biggest inhibition concentration is 1000 $\mu \mathrm{g} / \mathrm{ml}$ with the percentage of growth inhibition $41.62 \%$, and the incubation time is 48 hours, the biggest inhibition concentration is $1000 \mu \mathrm{g} / \mathrm{ml}$ with the percentage of growth inhibition $43.45 \%$. Based on the result and conclusion, it is suggested to conduct further research with an addition in incubation time of pineapple ethyl acetate fraction, and Thin Layer Chromatography (TLC) test should be conducted to find out the bioactive compound contained in pineapple ethyl acetate fraction.

\section{REFERENCES}

1. Kanker, kesadaran rendah, ancaman membesar. Kompas, 2011 Apr 11. [cited 2011 Jun 2]. Available from: http://health.kompas.com/.

2. Carroll WL, Finlay JL, editor. Cancer in children and adolescent. London: Jones and Bartlett Publisher; 2010 [cited 2010 Aug 10]. Available from: http:// www.books.google.co.id

3. Cure Research for Children's Cancer. Incidence. 2005 [cited 2010 Aug 10]. Available from: http://www.curesearch.org/.

4. Shafer WG, Hine MK, Levy BM. A Textbook of oral pathology. $4^{\text {th }}$ ed. New York: WB. Saunders; 1983. p. 121-9.

5. Cancer Help. Diagnosis kanker. 2004 [cited 2010 Jun 20]. Available from: http://www. cancerhelps.com/pengobatan-kanker-umum. htm.

6. National Cancer Institute. Chemotherapy side effects fact sheets. 2011 [cited 2011 Jan 18]. Available from: http://www.cancer.gov/ cancertopics/coping/chemo-side-effects.

7. Mangan Y. Cara bijak menaklukkan kanker. Jakarta: PT. AgroMedia Pustaka; 2003. p. 38-44.

8. Bangun AP. Jus buah dan sayuran untuk mengatasi kanker. Jakarta: PT. AgroMedia Pustaka; 2005.

9. Watson AA, Fleet GWJ, Asano N, Molyneux RJ, Nash RJ. Polyhydroxylated alkaloids natural occurance and therapeutic application. Phytochem 2001;56:265-95.

10. Tringali C. Bioactive compounds from natural sources. London: Taylor \& Francis: 2004. p. 433-72. 
11. Maurer HR. Bromelain: Biochemistry, pharmacology and medical use. Cell Mol Sci 2001;58:1234-45 [cited 2011 Jun 2] Available from: http: / /www.springerlink.com.

12. Heinrich M, Barnes J, Gibbons S, Williamson EM. Fundamentals of pharmacognosy and phytotherapy. London: Churchill Livingstone; 2004. p. $120-4$.

13. Mariod AA, Ibrahim RM, Ismail M, Ismail N. Antioxidant activity and phenolic content of phenolic rich fractions obtained from black cumin (Nigella sativa) seedcake. Food Chem 2009;116:306-12 [cited 2011 Mar 11] Available from: http: / /www.sciencedirect.com.

14. Schuldt EZ, Farias MR, Ribeiro-do-Valle RM, Ckles K. Comparative study of radical scavenger activities of crude extract and fraction from Cuphea carthagenensis leaves. Phytomed 2004;111:523-9 [cited 2011 Mar 11]. Available from: http: / /www.sciencedirect.com.

15. Vauzour D, Ana RM, Giulia C, Oruna-Concha MJ, Spencer JPE. Polyphenols and human health: prevention of disease and mechanism of action. J Nutr 2010;2(11):1106-31. [cited 2010 Nov 23] Available from: http://www. mdpi.com/journal/nutrients.

16. Erlund I. Review of the flavonoids quercetin, hesperetin, and naringenin. Dietary sources, bioactivities, bioavailability, and epidemiology. Nutr Res 2004;24:851-74. [cited 2011 Apr 6]. Available from: http://www.sciencedirect. com.

17. Singh S, Malik BK, Sharma DK. Proteinkinase $C$ in prostate cancer and herbal products: a bioformatics approach. IJIB 2007;1(2):72-87. [cited 2010 Jun 19]. Available from: http:// www.sciencedirect.com.

18. Biantoro I. Efektivitas fraksi etil asetat kulit manggis (Garcinia mangostana Linn.) terhadap hambatan pertumbuhan sel kanker lidah manusia Supri's Clone-1(SP-C1) [Thesis]. Bandung: Universitas Padjadjaran; 2011.

19. Supriatno, Yuletnawati. Aktifitas anti kanker cepharantine pada kanker lidah manusia in vitro (tinjauan proliferasi, invasi, dan metastasis sel). Yogyakarta: Maj Kedok Gigi UGM; 2006:141-5.

20. Phaneuf $H$. Herbal interaction with receptors and enzymes. In: Herbs demystified a scientist explains how the most common herbal remedies really work. New York: Marlowe and Co.; 2005. p. 371-3.

21. Artikel Sehat. Cerdas menggunakan herbal. 2011 [cited $2010 \mathrm{Apr}$ 16]. Available from: http: / / www.indoroyal.com/artikel-sehat / cerdas-menggunakan-herbal.html

22. Sutrisno BR. Reverse approach. Jakarta: Fakultas Farmasi Universitas Pancasila; 1986.

23. Hsiung WY, Kadir HA. Leea indica ethyl acetate fraction induces growth-inhibitory effect in various cancer cell lines and apoptosis in $\mathrm{Ca}$ skin human cervical epidermoid carcinoma cells. Evidence-based complementary and alternative medicine. 2011 [cited 2011 Jun 14]; Article ID 293060:1-13.

24. Poli PS. Komunikasi sel dalam biologi molekuler jalur sinyal dan implikasi klinis. Jakarta: Buku Kedokteran EGC; 2009: 47-96.

25. Qiagen. Activation of PKC through GPCR 2003 [cited 2011 Apr 11]. Available from: http:// www.qiagen.com.

26. Aberoumand A, Deokule SS. Comparison of phenolic compound of some edible plants of Iran and India. J Nutr 2008;7(4):582-5.

27. Williams RJ, Spencer JPE, Evans CR. Flavonoids: antioxidant or signalling molecules? Free Radical Biol and Med 2004;36(7):838-49. [cited 2011 Apr 10]. Available from: http:// sciencedirect.com.

28. Mhatre M, Tilak-Jain J, De S, Devasagayam TPA. Evaluation of the antioxidant activity of non-transformed and transformed pineapple: A comparative study. Food and Chemical Toxicology 2009;47:2696-702. [cited 2011 Jan 27]. Available from: http://sciencedirect.com.

29. Kang T, Liang N. Studies on the inhibitory effects of quercetin on the growth of HL-60 leukemia cells. Biochemical Pharmacology 1997;54:1013-8. [cited 2011 Apr 6]. Available from: http: / /www.sciencedirect.com

30. Woude H, Swiglo AG, Struijs K, Smeets A, Alink GM, Rietjens IMCM. Biphasic modulation of cell proliferation by quercetin at concentrations physiologically relevant in humans. Cancer Letters 2003;200:41-7 [cited 2011 Apr 6] Available from: http://www.sciencedirect.com. 